\title{
P057: Epidemiological aspects of MRSA circulation in the industrial region of Russia
}

\author{
EB Brusina*, LS Glazovskaya, TV Efimova \\ From 2nd International Conference on Prevention and Infection Control (ICPIC 2013) \\ Geneva, Switzerland. 25-28 June 2013
}

\section{Introduction}

Methicillin-resistant Staphylococcus aureus (MRSA) represent one of the major problems related to healthcare-associated infections (HAIs). Investigation of the regional features of MRSA circulation may lead to the improvement of the system of MRSA infection control.

\section{Objectives}

To study features of MRSA circulation in the industrial region of Russia.

\section{Methods}

MRSA identification and determination of susceptibility to antibiotics were performed using VITEK 2 identification cards (colorimetric reading). MRSA DNA was defined using real-time polymerase chain reaction (PCR) with fluorescent hybridization probes. MecA structural gene was determined by sequencing, identification of sea, seb, sec, tst, and pvl genes was performed using PCR. Identification of MRSA clonal profile was investigated by restriction-modification (RM)-test and by spa sequence typing.

\section{Results}

The share of MRSA among all strains of Staphylococcus aureus in 2012 was $16.63 \%$, that was almost 2-fold lower compared to 2007 (32.09\%), and from 2007 till 2012 a steady decrease of this value was noted. The prevalence of MRSA among healthy population was 13,25 per 1,000 . MRSA share among patients with bloodstream infections was the highest, reaching $21.85 \%$ (95\% $\mathrm{CI}=15.55-29.3)$. The lowest MRSA share was registered among patients with genital infections $(13.17 \%$, 95\% $\mathrm{CI}=11.1-15.49)$. In the burn units, the spread of MRSA reached epidemic level (80\%). We found that $49.25 \%$ of

Department of Epidemiology, Kemerovo State Medical Academy, Kemerovo, Russian Federation all strains were sea-positive, $85.07 \%$ were sec-positive, and $13.43 \%$ were tst-positive. No seb- or pvl-positive strains were identified. We also revealed using RM-test that our strains were mainly classified to $\mathrm{CC} 8 / 239$ clonal complex.

\section{Conclusion}

The measures of MRSA infection control should take into account regional features.

\section{Disclosure of interest}

None declared.

Published: 20 June 2013

\section{doi:10.1186/2047-2994-2-S1-P57}

Cite this article as: Brusina et al:: P057: Epidemiological aspects of MRSA circulation in the industrial region of Russia. Antimicrobial Resistance and Infection Control 2013 2(Suppl 1):P57.

\section{Submit your next manuscript to BioMed Central and take full advantage of: \\ - Convenient online submission \\ - Thorough peer review \\ - No space constraints or color figure charges \\ - Immediate publication on acceptance \\ - Inclusion in PubMed, CAS, Scopus and Google Scholar \\ - Research which is freely available for redistribution

